\title{
QUEEN'S
QNIVERSITY
BELFAST
}

\section{Perceived peer and school norm effects on youth antisocial and prosocial behaviours through intergroup contact in Northern Ireland}

McKeown, S., \& Taylor, L. K. (2018). Perceived peer and school norm effects on youth antisocial and prosocial behaviours through intergroup contact in Northern Ireland. British Journal of Social Psychology.

https://doi.org/10.1111/bjso. 12257

\section{Published in:}

British Journal of Social Psychology

\section{Document Version:}

Peer reviewed version

Queen's University Belfast - Research Portal:

Link to publication record in Queen's University Belfast Research Portal

\section{Publisher rights}

(C) 2018 The British Psychological Society.

This work is made available online in accordance with the publisher's policies. Please refer to any applicable terms of use of the publisher.

\section{General rights}

Copyright for the publications made accessible via the Queen's University Belfast Research Portal is retained by the author(s) and / or other copyright owners and it is a condition of accessing these publications that users recognise and abide by the legal requirements associated with these rights.

Take down policy

The Research Portal is Queen's institutional repository that provides access to Queen's research output. Every effort has been made to ensure that content in the Research Portal does not infringe any person's rights, or applicable UK laws. If you discover content in the Research Portal that you believe breaches copyright or violates any law, please contact openaccess@qub.ac.uk. 
Running head: intergroup norms, contact and behaviour

\title{
Peer and school norm effects on youth antisocial and prosocial behaviours through intergroup contact in Northern Ireland
}

\author{
Shelley McKeown and Laura K. Taylor \\ ${ }^{1}$ University of Bristol \\ ${ }^{2}$ Queen's University, Belfast
}

*Requests for reprints should be addressed to Shelley McKeown, 35 Berkeley Square, Bristol, United Kingdom (e-mail: s.mckeownjones@bristol.ac.uk).

\section{Acknowledgements}

This work was supported by the Richard Benjamin Trust and the British Academy(BA)/Leverhulme [SG 150807]. Thank you to Jeffrey Hanna, Alexandra Kenny, Clarissa Courtney, Lauren Brown, Dean O’Driscoll, Marion Schulz, Karolina Urbanska, Lukas Horstmeier, Sofia Chirtoglou and Yangjunru (Cecilia) Li for their support with data collection. Our deep appreciation to the numerous school administrators, teachers, and pupils for participating in this project. 


\begin{abstract}
In adolescence, youth spend a high proportion of their time with their peers and in school; it is hardly surprising therefore, that perceptions of peer and school norms have a strong influence on their attitudes and behaviours. These norms, however, do not always influence youth in the same way. Building on past research, the present study examines the role of peer norms and school norms in influencing the quantity and quality of intergroup contact, as well as the impact of such contact on positive and negative intergroup behaviours. Youth (aged 14-16) living in Northern Ireland $(\mathrm{N}=466$, evenly split by religion and gender) were recruited through their school as part of a two-wave study and completed a series of survey measures including intergroup contact (quality and quantity), norms (peer and school), participation in sectarian antisocial behaviour and outgroup prosocial behaviour. Mediation analysis was conducted in Mplus. Controlling for wave 1 responses on contact and behavioural outcomes, findings demonstrate that more positive peer norms are associated with less participation in antisocial behaviour and more participation in prosocial outgroup behaviours through increased and better quality intergroup contact. Positive school norms were also associated with increased prosocial behaviour, but only though better quality contact. Findings demonstrate the relative importance of peer norms compared to school norms for this age group. The results have implications for school-based interventions that aim to improve intergroup relations, and highlight the importance of peer networks to promote more positive outgroup behaviours in divided societies such as Northern Ireland.
\end{abstract}

Key words: intergroup contact; peer norms; school norms; prosocial behaviour; antisocial behaviour youth; sectarianism; intergroup conflict; Northern Ireland 


\section{Perceived peer and school norm effects on youth antisocial and prosocial behaviours through intergroup contact in Northern Ireland}

Social norms have long been established as important predictors of intergroup attitudes and behaviours stemming as far back as the classic studies of Sherif (1936). In the last few years, there has been a movement to consider more closely the role of peer and school norms for youth. In particular, examining how perceptions of both peer and school norms differently predict outcomes including intergroup attitudes, aggressive tendencies and interest in engaging in intergroup contact (Tropp et al., 2016). The present study extends this body of research by examining the differing role of peer and school norms in influencing the extent to which adolescents engage in frequent and quality contact and the consequence that this contact has on both positive and negative intergroup behaviours in the context of ethnoreligious relations in Northern Ireland. This is under the premise that norms influence the extent to which individuals engage or have interest in intergroup interactions (Tropp et al., 2016) and that they are associated with intergroup behaviours, both positive (e.g., altruism and helping, Berkowitz, 1972) and negative (e.g., aggressive tendencies, Nesdale \& Lawson, 2011).

The current study is uniquely situated in the context of Northern Ireland and makes a valuable contribution to the literature in a number of ways. First, reflecting a growing trend in the intergroup contact literature, it examines the the potential antecedents of school and peer norms in fostering both more frequently and better quality contact across group lines. Second, the two-wave study moves beyond attitudes and intentions to focus on self-reported measures of youth behaviour. Third, expanding on the traditional focus of prejudice reduction (McKeown \& Dixon, 2017), it considers both antisocial and prosocial intergroup behaviours, testing the potentially positive and negative role of norms on behaviours. Fourth, situated in a 
post-accord setting such as Northern Ireland, this study focuses on youth participants for whom the realities of living in a divided society and associated norms has important ramifications for future intergroup relations.

\section{Peer and School Norms}

Social norms are set within group situations and provide standards for and influence the formation of an individual's attitudes and behaviours (Sherif \& Sherif, 1953). Researchers agree that peer groups and thereby the norms set by a peer group, have a strong influence on children's attitudes and behaviours (Nesdale \& Lawson, 2011) and are arguably the most important predictor of children's behaviour (Nesdale, 2004). In an intergroup setting, for example, evidence demonstrates that for children, peer norms are associated with increased intentions towards cross-group friendship (Cameron, Rutland, Hossain \& Petley, 2011), increased comfort and willingness to engage in intergroup contact and cross-group friendships (Tropp, O'Brien, \& Migacheva, 2014; Tropp et al., 2016), and reduced intergroup anxiety (Tezanos-Pinto, Bratt, \& Brown, 2010). At the same time, ingroup norms can also be associated with negative intergroup attitudes, such as prejudice and discriminatory behaviours towards outgroup members (Crandall, Eshleman, \& O'Brien, 2002). These findings suggest that the valence and content of the peer norms are relevant for predicting both more constructive or positive, as well as more tense or negative, intergroup behaviours among young people.

Youth, however, are not only influenced by their peer groups. The school environment is also known to hold its own values and norms that influence adolescent attitudes and behaviour, beyond academic achievement (Wilson, 1959). For example, evidence shows that school norms of inclusion are associated with more positive outgroup attitudes (Nesdale \& Lawson, 2011) and that classroom environments which promote norms of non-aggression can reduce engagement in aggressive behaviours (Henry et al., 2000). 
School norms within the classroom have also been found to be associated with bullying related behaviours, both positive (i.e., helping the victim) and negative (i.e., engaging in bullying; Salmivalli \& Voeten, 2004). It is perhaps unsurprising, therefore, that there is a growing body of research focusing on examining the competing roles of peer and school norms on intergroup attitudes and behavioural intentions.

Evidence from the few studies conducted to date demonstrate the different ways in which peer and school norms work together and separately to influence intergroup attitudes. For example, in their work with children, Nipedal, Nesdale and Killen (2010) observed a main effect of group norms on children's aggressive intentions and that for young children, this relationship was moderated by inclusive school norms. Further, Tropp et al. (2016) found differential effects of peer and school norms such that peer norms were associated with comfort in contact, interest in cross-group friendships, increased contact quality and perceived discrimination, whereas school norms were associated with more interest in crossgroup friendships over time. Building on Nesdale and Lawson's (2011) research, McGuire, Rutland and Nesdale (2015) examined the effects of priming an inclusive school norm on intergroup attitudes. They found that a positive and inclusive school norm was more important than inclusive peer norms in promoting more positive outgroup attitudes, but only when children were held accountable by their teachers. Together, these findings demonstrate the importance of considering both peer and school norms when understanding the intergroup relations among school-aged children and young people.

\section{Norms and Intergroup Contact}

Several studies have focused on examining the impact that norms have on intergroup attitudes and the extent to which individuals are willing to and interested in engaging in cross-group contact (Tropp et al. 2014; Tropp et al., 2016). For example, Jasinskaja-Lahti, Mähönen, and Liebkind (2011) found that peer norms, along with intergroup contact, were 
important predictors of intergroup attitudes, while Feddes, Noack and Rutland (2009) found that social norms partially mediated the influence of cross-group friendship on outgroup attitudes. Further, Tropp et al. (2014) found that children's perceptions of inclusive peer norms were associated with greater desire for cross-group friendship for both majority and minority group members. Moreover, the success of extended contact, for example, is said to be underpinned by group norms. Evidence for this comes from Cameron et al. (2011) who found that effects of extended contact on cross-group friendship formation intentions were through ingroup and outgroup peer norms. Recent longitudinal studies have also found that broader contextual norms, such as at the neighbourhood level, also influence changes in intergroup bias over the course of adolescence (Merrilees et al., 2017). These findings are important because intergroup contact (Allport, 1954) is a well-known prejudice reduction tool (Pettigrew \& Tropp, 2006) and, along with norms, has been found to relate to reductions in negative intergroup behaviours and post-conflict reconciliation (Stathi, Husnu \& Pendleton, 2017).

It is argued here that there is a need to go beyond measures of attitudes and behavioural intentions to assess how these norms may shape intergroup contact experiences and thereby influence adolescents' positive and negative intergroup behaviours. That is, building on past research that integrates social norms and direct contact experiences, the current study will extend to consider self-reports of recent intergroup behaviours. Moreover, the dual set of peer and school norms has not been investigated in a setting of protracted intergroup conflict.

\section{Positive and Negative Youth Intergroup Behaviours}

As noted above, there is evidence to suggest that both social norms and direct contact experiences affect both positive and negative youth intergroup outcomes. Although the primary focus to date has been on self-reported attitudes and behavioural intentions, it is also 
possible to assess recent behaviours through such methods. Therefore, the current study investigates two important behavioural outcomes in a setting of protracted conflict: youth participation in sectarian antisocial behaviour and youth prosocial behaviour toward outgroup members. It is argued that these outcomes are key factors for potential long-term peacebuilding in a divided society. On the one hand, if a generation born after a peace agreement and end to formal conflict continues to engage in destructive and violent behaviours, such as physical altercations with youth from across the divide, this has the potential to prolong intergroup tensions and hostility (Taylor, Merrilees, Goeke-Morey, Shirlow, Cummings, 2016). On the other hand, if the 'post-accord' generation is more likely to engage in cross-group helping and constructive outgroup behaviours, this may represent important antecedent for improved intergroup relations and peacebuilding (Taylor et al., 2014; Taylor \& McKeown, 2017). Understanding these two types of outcomes during adolescence is important because the patterns established during this developmental period have been shown to have long-lasting effects into adulthood (Bowman, Brandenberger, Lapsley, Hill \& Quaranto, 2010). Thus, these are important not only as individual youth outcomes, but also have potential implications for the continuation of broader societal conflict (Punamaki, 2009; Taylor et al., 2014). This is particularly relevant in societies defined by a history of protracted intergroup conflict, such as Northern Ireland.

\section{Intergroup Relations in Northern Ireland}

From 1968 to 1998, the 'Troubles' represents the most recent period of intergroup violence in Northern Ireland. During this time, there were more than 3,600 politicallymotivated deaths and over 30,000 injuries (Fitzduff \& O’Hagan, 2009). However, the tensions in Northern Ireland date back much further (Hancock, 1998), and represent a protracted conflict between the Protestant and Catholic communities over historic, religious, political, economic and psychological elements (Cairns \& Darby, 1998). Following the 
signing of the 1998 Good Friday/Belfast Peace Accord, which largely resolved the underlying political disputes, the consequences of the conflict remain an everyday experience for many living in this society.

The present study focuses on Belfast where the participants, born after the 1998, represent a 'post-accord' generation. This cohort of young people is exposed to continued intergroup tension in the form of annual cycles of violence, particularly in the summer months, as well as persistent sectarianism. Past research has found that over $80 \%$ of adolescents have experienced some form of sectarianism directly or indirectly (Byrne, Conway \& Ostermeyer 2005). However, youth in Northern Ireland are not merely the passive victims of sectarianism. Young people often engage in the annual parades and marches in July, which frequently turn to rioting and violence (McEvoy-Levy, 2006). At the same time, there are a number of examples of the constructive ways that young people are contributing to the common good across Northern Irish society (Taylor et al., 2017). Therefore, by considering both positive and negative behaviours the current study also recognizes the peacebuilding potential of young people.

Both peer and school norms are particularly relevant in Northern Ireland, in part because of the segregated nature of daily life (Shirlow \& Murtagh, 2006). That is, through social patterns, the majority of individuals primarily interact with ingroup members. Therefore, in this context, peer norms represent the expectations of the ingroup (Turner, Tam, Hewstone, Kenworthy \& Cairns, 2013); if youth in Northern Ireland believe that their ingroup peers positively view interactions with the other community, or that they will not face social sanctions for interacting with outgroup members, this will influence their own direct contact experiences. Reinforcing the segregated nature of daily life, schools in Northern Ireland are also divided along community lines. That is, over $94 \%$ of young people attend either a Protestant Controlled or a Catholic Maintained school. Therefore, school 
norms arguably also represent ingroup norms with the same implications regarding contact across group lines. This may be particularly the case for children and young people who attend religiously segregated schools whereby school norms are linked with what it means to be an ingroup member, as well as teachers often being primarily members of the ingroup. Yet, school norms in this context may not influence outcomes, such as intergroup attitudes, over and above direct contact experiences (Hughes, Campbell, Lollilot, Hewstone, \& Gallagher, 2013). Therefore, in a divided society, studying both peer and school norms to understand how they may predict direct contact experiences and, in turn, intergroup outcomes, is particularly important.

\section{Present Research}

The current study builds on past research in a number of ways. First, it examines how perceptions of both peer and school norms, particularly around intergroup relations, influence both the quantity and quality of intergroup contact among adolescents in Belfast. This fits with the direction of research that aims to untangle the predictors of intergroup contact. Second, the study examines how both types of contact relate to positive and negative intergroup outcomes, specifically outgroup directed prosocial behaviours and participating in sectarian antisocial behaviour. Third, the research takes place in a society in which schools and community life are segregated by focusing on adolescents attending predominantly Protestant or Catholic schools in Northern Ireland.

Based on previous research, it was hypothesized that positive peer norms would be associated with increased quantity and quality of intergroup contact (see Jasinskaja-Lahti et al., 2011; Tropp et al., 2014), whereas this relation would be non-significant for positive school norms (in line with previous findings by Tropp et al., 2016). Second, it was expected that both positive peer and school norms would relate to more outgroup prosocial behaviours 
and less participation in sectarian antisocial behaviour. Third, it was hypothesized that the impact of peer norms on intergroup outcomes would be mediated by intergroup contact.

\section{Method}

\section{Participants and Procedures}

Participants were part of a two-wave study on positive youth development. Eight comprehensive schools, which include a range of academic abilities with a relatively similar level of pupils receiving free school meals (30 to 65\%), were recruited to take part in the research. Participating schools balanced controlled (i.e., predominately Protestant) and maintained (i.e., predominately Catholic) status, as well as interface and non-interface areas, in Northern Ireland. Initially, principals consented for Year 11 pupils to participate and parents were given the option to opt-out. Participating schools were also offered a modest monetary incentive of $£ 100$ that could be used for a class party or supplies to thank them for their participation.

Pupils who were not from the Catholic or Protestant community were excluded from the primary study, and completed an alternative version of an on-line questionnaire. All youth participants provided informed consent before participating which led to a sample of Year 11, ages $14-15$ years old $(\mathrm{N}=466,50 \%$ male, $50 \%$ female; $51 \%$ Catholic, $49 \%$ Protestant $)$ collected in Spring 2016 and Year 12, ages 15-16 years old $(\mathrm{N}=383,52 \%$ male, 48\% female; 47\% Catholic, 53\% Protestant) collected in Autumn 2016. Participants who completed both time points ( $80 \%$ from wave 1$)$ were compensated for their time with a $£ 10$ Amazon gift card. Attrition analyses revealed there were no significant differences on the wave 1 variables when comparing youth that did and did not return at wave 2 .

At each time point, data were collected in a single day by a trained team of research assistants. In collaboration with school teachers and administrators, the pupils individually completed the online questionnaire in Qualtrics group setting, typically organised in the IT 
classroom. The questionnaire took approximately 20-35 minutes to complete, based on the pupils' reading comprehension. The research team was on hand to answer any questions and address any technical issues that arose; if possible, a classroom teach from the school was also present during the course of data collection. All procedures were approved by the Ethics Committee at Anonymous University.

\section{Measures $^{1}$}

Peer norms. The measure for peer norms was adapted from Tropp et al. (2014). At wave 2, peer norms assessed the degree to which youth perceived others their age to be supportive of intergroup contact. This construct was measured by four items ranging from 0 (not at all) to 6 (very much) where participants were asked to respond to the extent to which they agreed with a series of statement including; "Young people from the <ingroup> community want to be friends with young people from the <outgroup> community," "Young people from the <ingroup> community would be happy if I became friends with youth from <outgroup> community," "Young people from the <ingroup > community encourage me to make friends with youth from the <outgroup> community" and "Youth from the <ingroup> community like it when I 'hang out' with young people from the <outgroup> community." Based on how participants self-identified in demographics section of the questionnaire, the ingroup and outgroup names were specified as either 'Protestant' or 'Catholic' using the piped text feature in Qualtrics. Higher scores indicated positive peer norms that were more supportive of intergroup contact and the scale had good internal consistency $(\alpha=.90)$.

School norms. The measure for school norms was also adapted from Tropp et al. (2014). At wave 2, school norms were measured by a similar four items ranging from 0 (not at all) to 6 (very much). In this case, the reference group was the participants' school

\footnotetext{
${ }^{1}$ Although peer and school norms were not assessed in wave 1 , following data collection and preliminary data analysis, the authors believed that norms may be affecting these processes and therefore chose to add these measures at wave 2 .
} 
principal and teachers: "My teachers and principal encourage me to be friends with young people from the <outgroup> community," "My teachers and principal would be happy if I became friends with youth from <outgroup> community," "My teachers and principal encourage me to make friends with youth from the <outgroup> community," and "My teachers and principal like it when I 'hang out' with young people from the <outgroup> community." Higher scores indicated more supportive school norms, also with good internal consistency $(\alpha=.92)$.

Intergroup contact. Two dimensions of intergroup contact were assessed: quantity and quality. The single-item measure for each dimension was adapted from Tam, Hewstone, Kenworthy and Cairns (2009), expanding the range of options to a 7-point Likert scale. For contact quantity, participants responded to the questions "How much contact do you have with people from the Protestant/Catholic community" ranging from 1 (none at all) to 7 (a great deal). Contact quality was assessed with the question "In general, when you meet people from the Protestant/Catholic community, do you find the contact pleasant or unpleasant” with responses ranging from 1 (very unpleasant) to 7 (very pleasant). Higher scores indicated greater quantity and quality contact, respectively. Participants were asked to answer these questions at both waves.

Participation in sectarian antisocial behaviour (PSAB). A previously established measure of PSAB that was developed for the case of Northern Ireland was used for this study (Taylor et al., 2016). At waves 1 and 2, participants were asked to read a list of behaviours and to report how often they have done each of these behaviours to get at someone from the outgroup community in the previous three months $(0=$ never, $1=$ not in the last 3 months, 2 = once in the past 3 months, 3 = every week, 4 = every month, 5 =every day). Behaviours included: "Flown a flag”, “Wore a football jersey to taunt/provoke people from the <outgroup> community", "Sang or chanted songs about the <outgroup> community", 
"Used text messaging, instant messaging, or other forms of communication like Facebook to taunt or tease someone from the <outgroup> community", "Threatened, shouted at, or called someone names”, “Taken part in protests or demonstrations (against the <outgroup> community)", "Chased someone in the street”, Thrown stones or other objects over walls", "Damaged or spray painted on property of the <outgroup> community (e.g., windows, cars, streetlights, bus shelters)", and "Beaten up (hit, punched, or kicked) someone from the <outgroup> community." Higher scores indicated great levels of participation in sectarianism over the previous three months (wave $1 \alpha=.91$; wave $2 \alpha=.88$ ).

Outgroup prosocial behaviours. The prosocial subscale of the child behaviour scale (Ladd \& Profilet, 1996; Ladd, Herald-Brown \& Andrews, 2009) was adapted to measure selfreports of youth prosocial behaviours (Taylor et al., 2014). At both time points, participants were asked to rate how much they agreed $(1=$ strongly agree to $7=$ strongly agree $)$ with a series of seven statements such as: "I help my peers," "I am kind towards other people," and "I am cooperative with other people. Second, to capture the extent to which those actions were directed specifically at outgroup members, participants were asked a follow up question: "Thinking about all these things, how often do you do these towards people from the < outgroup > community?" and responded on a 7-point Likert scale $(0=$ never, $6=$ very often). Higher scores indicated more prosocial outgroup behaviours (wave $1 \alpha=.91$; wave 2 $\alpha=.87)$.

\section{Results}

The means, standard deviations and bivariate correlations are in Table 1. The overall mediational model was tested in Mplus using bootstrapped mediation to assess the indirect effects; maximum likelihood estimation was used and the model was a good fit to the data ( $N$ $=466, \chi^{2}(147)=416.84, p<.05, \mathrm{TLI}=.89 ; \mathrm{CFI}=.92 ; \mathrm{RMSEA}=.062(\mathrm{CI}: .055, .069) ;$ SRMR $=.027 ; \mathrm{Hu} \&$ Bentler, 1999). Latent variables were created for peer and school 
norms; all other constructs were single item measures (e.g., contact quantity) or count variables (e.g., participation in sectarian antisocial behaviour). All endogenous predictors were allowed to correlate; the error variances of the two outcomes were also allowed to correlate.

\section{INSERT TABLE 1 ABOUT HERE}

Seven dummy variables were created to control for potential school effects; cluster modeling is not possible with fewer than twenty groups (Muthén, 2005) and so class effects were not examined. There was no effect of school on outgroup prosocial behaviours; however, two schools reported significantly more participation in sectarian antisocial behaviours. Both were all-boy schools, one Controlled $(\beta=.18, p<.01)$ and one Maintained $(\beta=.20, p<.01)$. In terms of the other control variables, compared to boys, there were no significant differences in participation in sectarian antisocial behaviour however, girls reported more outgroup prosocial behaviours $(\beta=.15, p<.01)$. There were no significant differences in the two outcomes between Catholic and Protestant participants.

In addition, the stability parameters and cross-lagged effects for quantity and quality of contact, as well as the two outcomes were included as controls. Over the two waves, quantity of contact at wave 1 predicted both quantity $(\beta=.49, p<.001)$ and quality, but only at the trend level $(\beta=.11, p<.10)$ at wave 2 , whereas quality contact at wave 1 only predicted quality $(\beta=.28, p<.001)$ contact at wave 2 , but not quantity. For the outcomes over the two waves, the stability parameters were both significant, but the cross-lagged effects were not. That is, earlier outgroup prosocial behaviours $(\beta=.25, p<.001)$ and participation in sectarian antisocial behaviour $(\beta=.42, p<.001)$ predicted later levels of each variable at wave 2, respectively; however, earlier outgroup prosocial behaviours did not relate to later sectarian antisocial behaviours, and vice versa. Finally, taking the various 
predictors and stability parameters into account, there was no longer a significant relation between outgroup prosocial and participation sectarian antisocial behaviours at wave 2 .

Regarding the primary paths of interest in the mediation model (Figure 1), peer norms significantly predicted more frequent $(\beta=.34, p<.001)$ and better quality $(\beta=.35, p<.001)$ contact, whereas school norms did not. In terms of the two behavioural outcomes, contact quantity was positively related to more outgroup prosocial behaviours $(\beta=.30, p<.001)$, but not significantly related to more participation in sectarian antisocial behaviours. Better quality contact was related to more outgroup prosocial behaviours $(\beta=.17, p<.01)$ and to lower levels of participation in sectarian antisocial behaviours $(\beta=-.28, p<.001)$. The direct effects from norms to the outcomes not accounted for by the role of intergroup contact were examined next. Peer norms, on the one hand, related to more outgroup prosocial behaviours at the trend level $(\beta=.11, p=.09)$, but not to participation in sectarian antisocial behaviour. School norms, on the other hand, were not related participation in sectarian antisocial behaviour or outgroup prosocial behaviours.

\section{INSERT FIGURE 1 ABOUT HERE}

The indirect effects were examined next using bootstrapped confidence intervals with 1,000 replications. The impact of peer norms on outgroup prosocial behaviours through both quantity and quality of intergroup contact was significant. That is, peer norms were related to outgroup prosocial behaviours through more frequent $(\beta=.185,95 \% \mathrm{CI} .095, .300)$ and better quality $(\beta=.108,95 \% \mathrm{CI} .030, .203)$ contact. At the same time, peer norms also related to lower levels of participation in sectarian antisocial behaviour through better quality contact ( $\beta$ $=-.056,95 \% \mathrm{CI}-.094,-.033)$; more frequent contact, however, did not mediate the link from peer norms to participation in sectarian antisocial behaviour. This pattern of findings suggests that peer norms that are supportive of cross-group contact are related to greater quality and frequency of contact which are linked with positive outgroup prosocial behaviours. These 
supportive peer norms may help to reduce participation in sectarianism through better quality contact. Regarding the impact of school norms on positive and negative outgroup behaviours through intergroup contact, there were no significant indirect paths. ${ }^{2}$

\section{Discussion}

Focusing on adolescents in Northern Ireland, the present research examined how perceptions of peer and school norms associated with intergroup relations influenced both quantity and quality of intergroup contact and in turn outgroup prosocial behaviours and participating in sectarian antisocial behaviour. Based on previous research, hypothesis 1 predicted that positive peer norms would be associated with increased quantity and quality of intergroup contact, whereas this relation would be non-significant for positive school norms. Hypothesis 2 outlined how both positive peer and school norms would relate to more outgroup prosocial behaviours and less participation in sectarian antisocial behaviour. Finally, hypothesis 3 predicted that impact of peer norms on positive and negative intergroup outcomes would be mediated by intergroup contact.

In support of hypothesis 1 , findings demonstrated that positive peer norms were associated with more frequent and better quality intergroup contact. There was no significant relationship between school norms and either quality or quantity of contact in this sample. This finding replicates previous research by Tropp et al. (2016) who found differential effects of norms such that peer norms were associated with increased contact quality whereas school norms were associated with more interest in cross-group friendships over time.

In partial support of hypothesis 2 , peer norms were found to be directly related to more outgroup prosocial behaviours at the trend level $(p=.09)$, but not to participation in sectarian antisocial behaviour. This suggest that at least for this particular sample, positive

\footnotetext{
2 The results stayed the same when conducted with a revised scale of participation in sectarian antisocial behaviours, without the $4^{\text {th }}$ item that included social media and online forms of participation.
} 
peer norms may be important in promoting more positive outgroup behaviours, but do not influence the more destructive forms of participation in society. More research, however, is needed to examine this trend level effect. In contrast, school norms were not related to either participation in sectarian antisocial behaviour or to outgroup prosocial behaviours. Taken together, these findings not only offer further support for the differential effects of peer and school norms established in previous research (e.g., Tropp et al., 2014; 2016), but also suggest that it is particularly important for adolescents to be exposed to positive peer norms as they may be important antecedents for improved intergroup relations and peacebuilding (Taylor et al., 2014; Taylor \& McKeown, 2017).

Good quality intergroup contact was found to be associated with more outgroup prosocial behaviours and lower levels of participation in sectarian antisocial behaviour. High quantity contact was associated with more outgroup prosocial behaviours but was not found to be associated with participation in sectarian antisocial behaviour. In partial support of hypothesis 3 , results showed that positive peer norms were related to more outgroup prosocial behaviours through more frequent and better quality contact. Further, more positive peer norms were also related to less participation in sectarian antisocial behaviour through better quality contact. By contrast, there was no observed indirect effect of contact on the relation between school norms and either outgroup prosocial behaviours or participation in sectarian antisocial behaviour. This set of findings suggests that quality and quantity contact relate to positive and negative intergroup outcomes in distinct ways. As such, the mediational role of direct contact in the link from norms to self-reported behaviours varies. For example, supportive peer norms related to more outgroup prosocial behaviours through contact. However, peer norms may reduce participation in sectarianism through quality contact, more frequent contact was associated with greater participation in such negative outgroup acts. 
Taken together, the findings demonstrate the relative importance of peer norms compared to school norms for this age group in the context of Northern Ireland. The results suggest that it is particularly important, therefore, to better understand the role of peer networks in post-accord settings and to target interventions in a way in which promotes positive and inclusive peer norms. Moreover, the findings highlight the need to better understand the nature of both positive and negative forms of participation in society. Finally, although these findings are based on a very particular context, they could be relevant to other post-accord settings with fraught intergroup relations.

\section{Limitations and Future Directions}

The current study makes a number of valuable contributions to understanding the predictors and outcomes of intergroup contact; however, there are a number of limitations of this work. First, this study only includes two time points of data and norms were not measured at the first wave. As a consequence, interpretation about the direction of effects is limited. Future research should aim to examine how these processes unfold over at least three time-points. Second, the age range in the current study is limited to 14-16 years old; it would be interesting, for example, to compare the relative impact of peer and school norms in early, mid and late adolescence (Cameron et al., 2011; Crandall et al., 2002; Tropp et al., 2014: 2016). Moreover, this study focuses on a very specific context and therefore needs to be replicated in other post-accord settings.

Third, our measure of school norms aimed to capture school norms of contact, but arguably this measure is linked with authority; therefore, considering and understanding how school norms within and outside the realm of authority and how these impact intergroup attitudes and behaviours is an important direction for future research. Fourth, although a complement to prior research on behavioural intentions, our outcome measures of outgroup prosocial behaviour and sectarian antisocial behaviour are still self-reported behaviour. Given 
the sensitivity of this particular research topic, it would be difficult to examine real-life observable behaviours in this context. Measurement could also be strengthened for contact and prosocial behaviours that were assessed with single items due to time constraints. This approach has a limited ability to control for earlier effects in these constructs because of possible discrepancies due to measurement error; although the stability parameters were significant, those effects can only be partially controlled for, which may lead to an overestimation of the other pathways in the model. Future research could address these limitations with more robust scales or through experimental designs to capture actual behaviours through game-like tasks. In addition, the participation in sectarian antisocial behaviour scale included both face-to-face and on-line acts; future research should more closely consider the antecedents of sectarian behaviour in these two formats.

Despite these limitations, this research makes an important contribution to a number of bodies of research literature, including the differential effects of peer and school norms on youth outcomes, the impact of norms on positive and negative behaviours, and understanding how to promote better community relations amongst adolescents living in post-accord contexts. 


\section{References}

Allport, G.W. (1954). The Nature of Prejudice. Reading, MA: Addison-Wesley.

Berkowitz, L. (1972). Social norms, feelings, and other factors affecting helping and altruism. Advances in experimental social psychology, 6, 63-108.

Bowman, N., Brandenberger, J., Lapsley, D., Hill, P., \& Quaranto, J. (2010). Serving in College, Flourishing in Adulthood: Does Community Engagement During the College Years Predict Adult Well-Being?. Applied Psychology: Health and Well-Being, 2, 1434.

Byrne, J., Conway, M., \& Ostermeyer, M. (2005). Young people's attitudes and experiences of policing, violence and community safety in North Belfast. Belfast: Institute for Conflict Research.

Cairns, E., \& Darby, J. (1998). The conflict in Northern Ireland: Causes, consequences and controls. American Psychologist, 53, 754-760.

Cameron, L., Rutland, A., Hossain, R., \& Petley, R. (2011). When and why does extended contact work? The role of high quality direct contact and group norms in the development of positive ethnic intergroup attitudes amongst children. Group Processes \& Intergroup Relations, 14(2), 193-206.

Crandall, C. S., Eshleman, A., \& O'brien, L. (2002). Social norms and the expression and suppression of prejudice: the struggle for internalization. Journal of personality and social psychology, 82(3), 359.

Hancock, L. (1998). Northern Ireland: Troubles brewing. Retrieved from http://cain.ulst.ac.uk.

Henry, D., Guerra, N., Huesmann, R., Tolan, P., VanAcker, R., \& Eron, L. (2000). Normative influences on aggression in urban elementary school classrooms. American journal of community psychology, 28, 59-81. 
Hu, L. T., \& Bentler, P. M. (1999). Cutoff criteria for fit indexes in covariance structure analysis: Conventional criteria versus new alternatives. Structural equation modeling: a multidisciplinary journal, 6, 1-55. Doi: 10.1080/10705519909540118.

Hughes, J., Campbell, A., Lolliot, S., Hewstone, M., \& Gallagher, T. (2013). Inter-Group Contact at School and Social Attitudes: Evidence from Northern Ireland. Oxford Review of Education, 39, 761-779.

Feddes, A. R., Noack, P., \& Rutland, A. (2009). Direct and extended friendship effects on minority and majority children's interethnic attitudes: A longitudinal study. Child Development, 80, 377-390. doi:10.1111/j.1467-8624.2009.01266.x

Fitzduff, M., \& O’Hagan, L. (2009). The Northern Ireland Troubles: INCORE background paper. Retrieved http://cain.ulst.ac.uk.

Jasinskaja-Lahti, I., Mähönen, T. A., \& Liebkind, K. (2011). Ingroup norms, intergroup contact and intergroup anxiety as predictors of the outgroup attitudes of majority and minority youth. International Journal of Intercultural Relations, 35, 346-355.

Ladd, G. W., \& Profilet, S. M. (1996). The Child Behavior Scale: A teacher-report measure of young children's aggressive, withdrawn, and prosocial behaviors. Developmental Psychology, 32, 1008-1024.

Ladd, G. W., Herald-Brown, S., \& Andrews, R. K. (2009). The child behavior scale (CBS) revisited: A longitudinal evaluation of CBS subscales with children, preadolescents, and adolescents. Psychological Assessment, 21, 325-339.

McEvoy-Levy, S. (2006). Troublemakers or Peacemakers? Youth and Post-Accord Peacebuilding. Notre Dame, IN: University of Notre Dame Press.

McGuire, L., Rutland, A., \& Nesdale, D. (2015). Peer group norms and accountability moderate the effect of school norms on children's intergroup attitudes. Child development, 86, 1290-1297. 
Merrilees C.E., Taylor, L.K., Baird, R., Goeke-Morey, M.C., Shirlow, P., \& Cummings E.M. (2017). Neighborhood effects of intergroup contact on change in youth intergroup bias. Journal of Youth and Adolescence. Doi: 10.1007/s10964-017-0684-6. [Epub ahead of print]

Muthén, B. (2005). Mplus Discussion: Multilevel Data / Complex Sample. Retrieved from http://www.statmodel.com/discussion/messages/12/587.html?1488506083

Nesdale, D. (2004). Social identity processes and children's ethnic prejudice. In M. Bennett \& F. Sani (Eds.), The development of the social self (pp. 219-245). Hove, UK: Psychology Press.

Nesdale, D., \& Lawson, M. J. (2011). Social groups and children's intergroup attitudes: Can school norms moderate the effects of social group norms?. Child development, 82, 1594-1606.

Pettigrew, T. F., \& Tropp, L. R. (2006). A meta-analytic test of intergroup contact theory. Journal of Personality and Social Psychology, 90, 751-783.

Punamaki, R. L. (2009). War, military violence, and aggressive development: Child, family, and social preconditions. In B. K. Barber (Ed.), Adolescents and war: How youth deal with political violence (pp. 62-80). New York, NY: Oxford University Press.

Nipedal, C., Nesdale, D., \& Killen, M. (2010). Social group norms, school norms, and children's aggressive intentions. Aggressive behavior, 36, 195.

Salmivalli, C., \& Voeten, M. (2004). Connections between attitudes, group norms, and behaviour in bullying situations. International Journal of Behavioral Development, 28, 246-258.

Sherif, M. (1936). The psychology of social norms. New York: Harper.

Sherif, M., \& Sherif, C. W. (1953). Groups in harmony and tension; an integration of studies of intergroup relations. New York: Harper. 
Shirlow, P., \& Murtagh, B. (2006). Belfast: Segregation, violence and the city. Chicago, IL. Pluto Press.

Stathi, S., Husnu, S., \& Pendleton, S. (2017). Intergroup Contact and Contact Norms as Predictors of Postconflict Forgiveness. Group dynamics, theory, research and practice 21, 20-39. Doi: 10.1037/gdn0000060

Tam, T., Hewstone, M., Kenworthy, J., \& Cairns, E. (2009). Intergroup trust in Northern Ireland. Personality and Social Psychology Bulletin, 35, 45-59.

Taylor, L.K., Merrilees, C.E., Goeke-Morey, M.C., Shirlow, P., Cairns, E., \& Cummings, E.M. (2014). Political violence and adolescent outgroup attitudes and prosocial behaviors: Implications for positive intergroup relations. Social Development, 23, 840-859.

Taylor, L.K., Merrilees, C.E., Goeke-Morey, M.C., Shirlow, P., \& Cummings, E.M. (2016). Trajectories of adolescent aggression and family cohesion: The potential to perpetuate or ameliorate political conflict. Journal of Clinical Child and Adolescent Psychology, 45, 114-128.

Taylor, L.K., \& McKeown, S. (2017). Youths' peacebuilding potential: Intergroup contact and civic participation amongst a post-accord generation in Northern Ireland. In K. Niven, S. Lewis, \& C. Kagan (Eds.), Making a difference with psychology (pp. 5662). London, UK: Richard Benjamin Trust.

Taylor, L.K., Townsend, D., Merrilees, C.E., Goeke-Morey, M.C., Shirlow, P., \& Cummings, E.M. (2017). Adolescent civic engagement and perceived political conflict: The role of family cohesion. Youth \& Society. Doi 10.1177/0044118X17697236 
Tezanos-Pinto, P., Bratt, C., \& Brown, R. (2010). What will the others think? In-group norms as a mediator of the effects of intergroup contact. British Journal of Social Psychology, 49, 507-523.

Tropp, L. R., O'Brien, T. C., \& Migacheva, K. (2014). How peer norms of inclusion and exclusion predict children's interest in cross-ethnic friendships. Journal of Social Issues, 70, 151-166.

Tropp, L. R., O'Brien, T. C., González Gutierrez, R., Valdenegro, D., Migacheva, K., de Tezanos-Pinto, P., Burger, C., \& Cayul, O. (2016). How School Norms, Peer Norms, and Discrimination Predict Interethnic Experiences Among Ethnic Minority and Majority Youth. Child Development, 87, 1436-1451.

Turner, R. N., Tam, T., Hewstone, M., Kenworthy, J., \& Cairns, E. (2013). Contact between catholic and protestant schoolchildren in Northern Ireland. Journal of Applied Social Psychology, 43, 216-228.

Wilson, A. B. (1959). Residential segregation of social classes and aspirations of high school boys. American sociological review, 836-845. 
Table 1

Means, standard deviations and bivariate correlations for all study variables $(N=466)$

\begin{tabular}{|c|c|c|c|c|c|c|c|c|c|c|c|c|c|c|}
\hline & & $\mathrm{M}$ & $\mathrm{SD}$ & 1 & 2 & 3 & 4 & 5 & 6 & 7 & 8 & 9 & 10 & 11 \\
\hline 1 & Protestant (T1) & $\begin{array}{c}50 \% \mathrm{P} \\
50 \%\end{array}$ & $\begin{array}{l}\text { esant, } \\
\text { holic }\end{array}$ & - & & & & & & & & & & \\
\hline 2 & Girl (T1) & $\begin{array}{r}50 \% \\
50 \%\end{array}$ & $\begin{array}{l}\text { nale, } \\
\text { ale }\end{array}$ & $-.54^{* *}$ & - & & & & & & & & & \\
\hline 3 & $\begin{array}{l}\text { Quantity Contact } \\
\text { (T1) }\end{array}$ & 2.60 & 2.09 & .05 & .05 & - & & & & & & & & \\
\hline 4 & $\begin{array}{l}\text { Quality Contact } \\
\text { (T1) }\end{array}$ & 4.54 & 1.70 & .01 & .08 & $.55^{* *}$ & - & & & & & & & \\
\hline 5 & $\begin{array}{l}\text { Outgroup } \\
\text { Prosocial } \\
\text { Behaviour (T1) }\end{array}$ & 2.22 & 1.91 & .01 & $.11^{*}$ & $.43^{* *}$ & $.31^{* *}$ & - & & & & & & \\
\hline 6 & $\begin{array}{l}\text { Participation in } \\
\text { Sectarian } \\
\text { Antisocial } \\
\text { Behaviour (T1) }\end{array}$ & 0.61 & 0.96 & .05 & $-.19^{* *}$ & $-.15^{* *}$ & $-.30^{* *}$ & -.07 & - & & & & & \\
\hline 7 & $\begin{array}{l}\text { Quanty Contact } \\
\text { (T2) }\end{array}$ & 2.78 & 2.02 & .05 & .04 & $.64^{* *}$ & $.42^{* *}$ & $.36^{* *}$ & $-.14^{* *}$ & - & & & & \\
\hline 8 & $\begin{array}{l}\text { Quality Contact } \\
\text { (T2) }\end{array}$ & 4.83 & 1.67 & .02 & $.13^{* *}$ & $.41^{* *}$ & $.46^{* *}$ & $.28^{* *}$ & $-.23^{* *}$ & $.53^{* *}$ & - & & & \\
\hline 9 & $\begin{array}{l}\text { Outgroup } \\
\text { Prosocial } \\
\text { Behaviour (T2) }\end{array}$ & 2.43 & 1.87 & -.050 & $.21^{* *}$ & $.45^{* *}$ & $.34^{* *}$ & $.44^{* *}$ & $-.21^{* *}$ & $.54^{* *}$ & $.49^{* *}$ & - & & \\
\hline 10 & $\begin{array}{l}\text { Participation in } \\
\text { Sectarian } \\
\text { Antisocial } \\
\text { Behaviour (T2) }\end{array}$ & 0.39 & 0.59 & .078 & $-.26^{* *}$ & $-.15^{* *}$ & $-.26^{* *}$ & -0.09 & $.51^{* *}$ & $-.14^{* *}$ & $-.37^{* *}$ & $-.23^{* *}$ & - & \\
\hline 11 & Peer Norms (T2) & 2.86 & 1.37 & -.080 & $.14^{* *}$ & $.35^{* *}$ & $.27^{* *}$ & $.20^{* *}$ & $-.15^{* *}$ & $.52^{* *}$ & $.47^{* *}$ & $.41^{* *}$ & $-.17^{* *}$ & - \\
\hline 12 & $\begin{array}{l}\text { School Norms } \\
\text { (T2) }\end{array}$ & 3.51 & 1.54 & -.019 & $.17^{* *}$ & $.23^{* *}$ & $.21^{* *}$ & $.21^{* *}$ & $-.19^{* *}$ & $.30^{* *}$ & $.27^{* *}$ & $.28^{* *}$ & $-.24^{* *}$ & $.38^{* *}$ \\
\hline
\end{tabular}

Note: $* p<.05, * * p<.01$ 
Figure 1. Mediation model for peer and school norms on participation in sectarian antisocial behaviour and outgroup prosocial behaviours through quantity and quality contact among adolescents in Belfast across two waves. Control variables of school dummy codes, gender and community background, as well as wave 1 stability and cross-lagged effects of contact frequency and quality, and participation in sectarian antisocial behaviour and outgroup prosocial behaviours are reported in the text, but left out of the figure for readability. All endogenous predictors were allowed to correlate; the residual error variances of the two outcomes were also allowed to correlate. Standardized path coefficients are reported and error variances are omitted from the model for readability. Indirect parameter estimates are reported in the text. Black full lines represent significant paths; dashed lines represent trends; and dotted lines are non-significant. ${ }^{\dagger} p<.10,{ }^{*} p<.05,{ }^{* *} p<.01$,

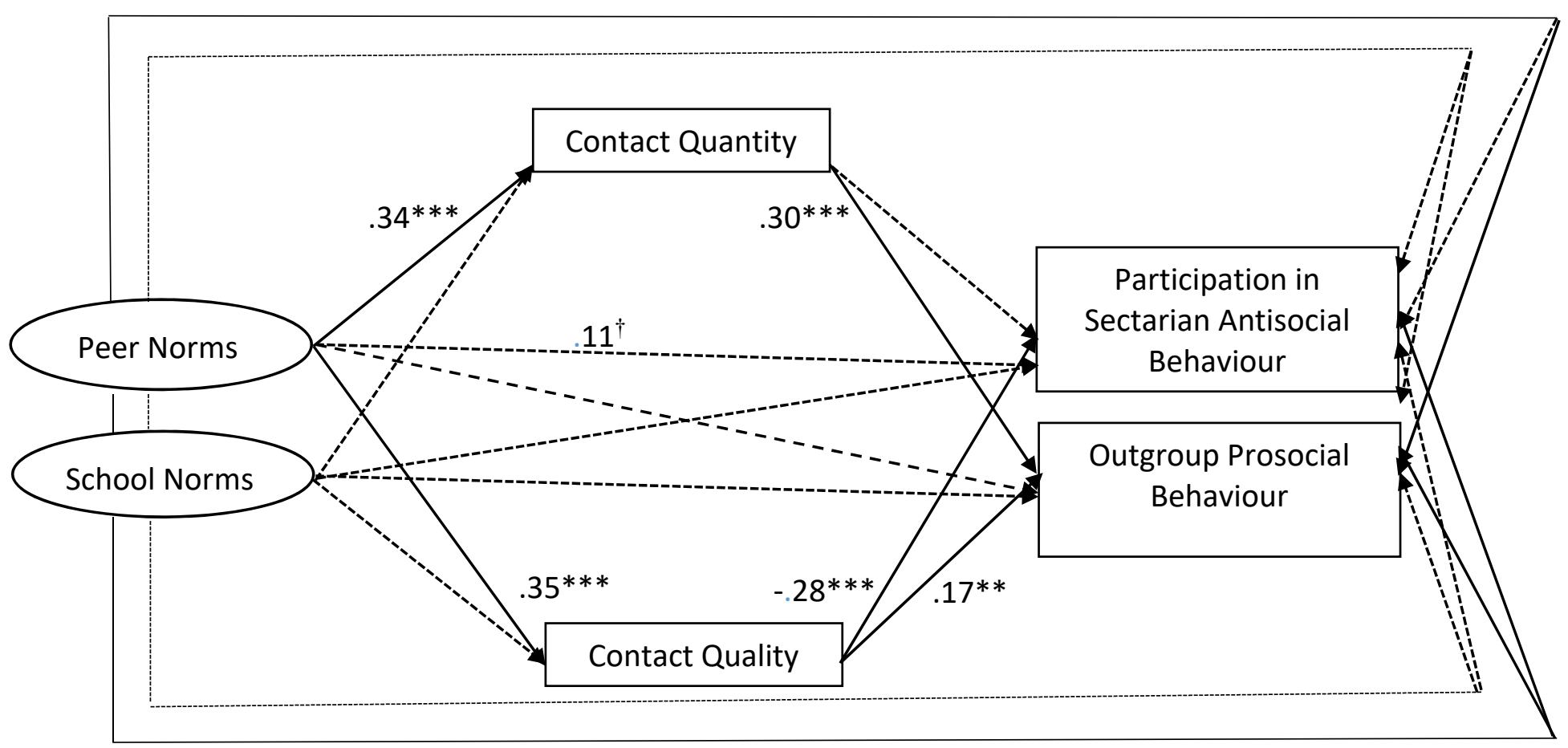

$* * * p<.001$. Model Fit: $N=466, \chi^{2}(147)=416.84, p<.05, \mathrm{TLI}=.89 ; \mathrm{CFI}=.92 ; \mathrm{RMSEA}=.062(\mathrm{CI}: .055, .069) ; \mathrm{SRMR}=.027$ 
INTERGROUP NORMS, CONTACT AND BEHAVIOUR 28 